\title{
THE SHANGHAI COOPERATION ORGANISATION'S MOMENTUM TOWARDS A MATURE SECURITY ALLIANCE
}

\author{
Dr Marcel de Haas*
}

\section{Netherlands Institute of International Relations, The Hague}

\section{Introduction}

Security organisations can differ in their scope of activities and in deepness of their mutual cooperation. For instance, the North Atlantic Treaty Organisation (NATO) nowadays pays homage to the broad concept of security: security not only encompassing military but also political, economic, social and environmental factors. ${ }^{1}$ Among other things, this comprehensive approach to security includes aspects such as free and fair elections; well-organised administrative, lawenforcement and judicial organs at national, regional and local level; employment; housing; education and health services. If all of these dimensions of security are provided in the areas where NATO operates, such as Bosnia, Kosovo and Afghanistan, then a stable and secure situation has been reached. However, in 1949 NATO started as an organisation with an exclusive military objective, namely to deter an eventual attack by the Soviet Union and its satellites against European (NATO) countries. Especially during its operations in the former Yugoslavia in the 1990s, the Western alliance realised that its concept of security should include other aspects than military, in order to achieve a stable international security environment. As to the intensity of cooperation among its member-states, NATO started with the most essential elements of political and military cooperation only. It took NATO many years to establish its current integrated political-military structure and activities, such as frequent political deliberations, joint forces and allied operations far beyond its territorial borders.

\footnotetext{
* Lieutenant-Colonel Royal Netherlands Army Dr. M. de Haas is Senior Research Fellow, Netherlands Institute of International Relations at Clingendael in The Hague.

${ }^{1}$ NATO Handbook 2006, Brussels, pp. 18-19.
} 
This article focuses on the Shanghai Cooperation Organisation (SCO), sometimes rather prematurely referred to as 'The NATO of the East'. In concentrating on its security-related aspects, this work will analyse the SCO's development towards a full-grown security organisation i.e., on its way to an alliance with a span of activities and a depth of cooperation similar to that of NATO. However, in doing so the focus remains on the SCO, not on a comparison with the Western alliance.

\section{Background to the SCO}

The SCO is a regional international organisation comprising states in Europe, the Near East, Central Asia and South East Asia. ${ }^{2}$ The SCO has China, Russia, Kazakhstan, Kyrgyzstan, Tajikistan and Uzbekistan as member states and Mongolia, Iran, Pakistan and India as observer states. ${ }^{3} \mathrm{SCO}$ member states have a population of nearly 1,5 billion people, which is about a quarter of the total world population. Including the four observers, the SCO encompasses nearly half the world's population. In addition to the member states Russia and China, the observers India and Pakistan bring together in the SCO four states with nuclear weapons Furthermore, the Chinese and Russian armed forces are amongst the three largest armed forces in the world. ${ }^{4}$ The SCO provides cooperation in political, military, economic, energy and cultural fields. Important ingredients of economic cooperation are (conventional) arms trade - with Russia as supplier - and energy, of which Russia, Kazakhstan, Uzbekistan and Iran are big exporters - while China and India are significant importers. Russia and China, however, remain the leading actors of the SCO.

${ }^{2}$ This article is partly derived from M. de Haas (Ed.), The Shanghai Cooperation Organisation: Towards a full-grown security alliance?, Clingendael Security Paper 3, The Hague, Clingendael Institute, November 2007. http://www.clingendael.nl/ publications/2007/20071100_cscp_security_paper_3.pdf.

${ }^{3}$ In practise, the observer states participate in many of the activities of the SCO, such as the annual summits, and as observers at military exercises. Their position is specifically mentioned in the regulations of the SCO Energy Club. Therefore, their status is more than simply that of observer.

4 Brief introduction to the Shanghai Cooperation Organisation, http://www.sectsco.org/html/00026.html; The SCO members and observers account for some 2,7 billion people out of 6,4 billion of the world population (Source: 2005 World Population Data Sheet, www.prb.org); http://www.nationmaster. com/red/graph/mil_arm_for_per-military-armed-forces-personnel\&b_printable=1. 


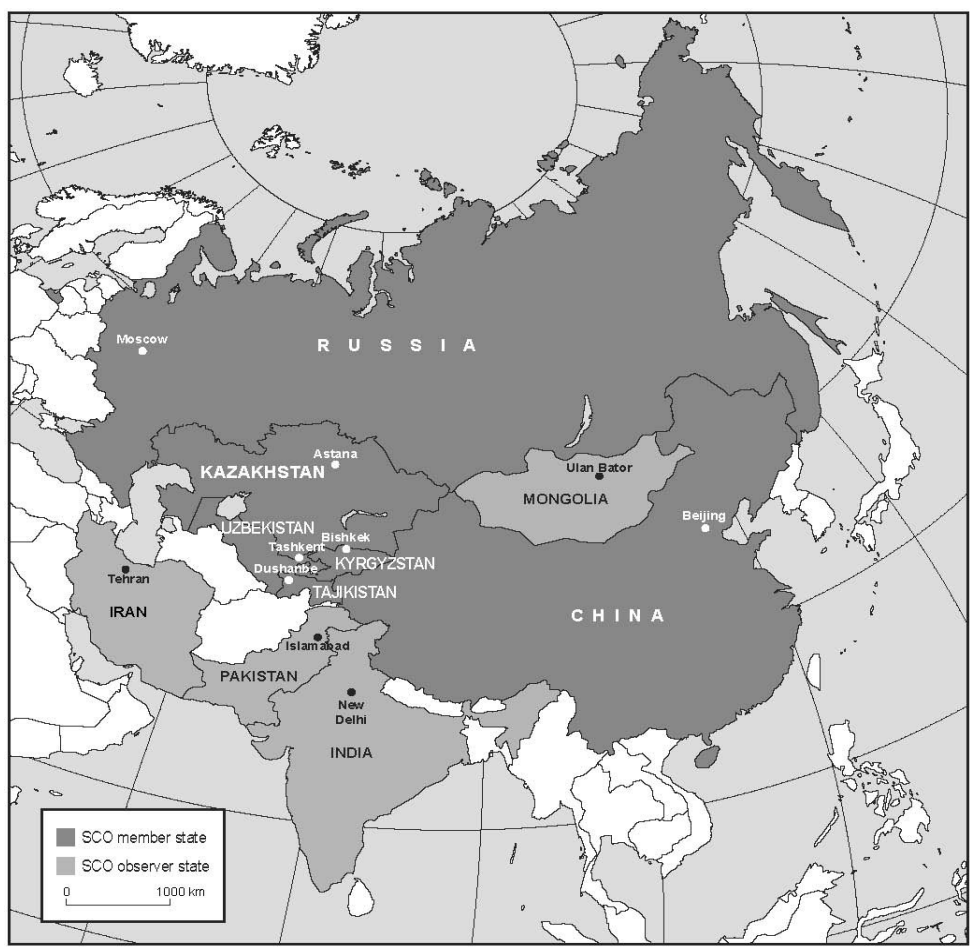

\section{Map 1: Member-states and observers of the SCO}

Source: A. J. K. Bailes, P. Dunay, P. Guang and M. Troitskiy, The Shanghai Cooperation Organization, SIPRI Policy Paper no. 17 (Stockholm International Peace Research Institute, May 2007), available at http://books.sipri.org.

Although the SCO started as a security organisation - extending from confidence-building measures at the borders to anti-terrorist activities - SCO members frequently state that this organisation is primarily meant for political and economic cooperation and that military coordination - focussing on domestic security - plays a minor role. For instance, the Russian Deputy Defence Minister, Sergei Razov, denied allegations that military cooperation among SCO members is a top priority and stated that economic cooperation and security are the main interests. Likewise, at the SCO Bishkek Summit of August 2007, President Putin denied that 


\section{7}

the SCO would develop into a full-grown security organisation such as NATO. ${ }^{5}$ So far, neither individual members nor the organisation itself has made any statements towards the intention to create what some Western commentators call a 'NATO of the East'. Furthermore, SCO members disagree upon vital issues of security, as was the case with the anti-Western positions in the declaration of the 2005 Astana Summit concerning Western military deployment in Central Asia and also on other issues of security cooperation. For instance, in terms of the international legal connotation of security, there is common understanding within the SCO that 'noninterference' in internal affairs is a leading principle. Accordingly, SCO members refuse Western criticism on their human rights practises. However, when it comes to collective action against domestic, non-violent uprisings, the March 2005 revolution in Kyrgyzstan demonstrated disagreement within the SCO whether to act or not, with China allegedly in favour and Russia against military intervention. ${ }^{6}$

Considering its recent security activities, is the SCO developing into a 'NATO of the East' as it was regularly described after the anti-Western flavour of the 2005 Astana Summit? In the last couple of years, the SCO indisputably made huge steps in intensified security cooperation, operational (military exercises), as well as political (policy concepts). A number of events and agreements in 2006 and 2007 indicate a cautious development of the SCO towards a full-grown security organisation. In analysing the current and future developments of the SCO, this article concentrates on indications of increased security cooperation, the relationship with the Collective Security Treaty Organisation (CSTO), energy security and the connections with the West.

\section{Steps towards closer security cooperation}

In spite of the frequent denials of the military nature of the SCO and the differences between members regarding military and security cooperation, five recent developments can be discerned which point in the direction of the SCO gradually moving towards a full-grown security organisation.

5 F. W. Stakelbeck Jr., 'The Shanghai Cooperation Organization', FrontPageMagazine.com, 8 August 2005, http://www.frontpagemag.com/Articles/ Printable.asp?ID=19041; 'ShOS ne nado sravnivat s NATO, schitayet Putin', RIA Novosti, 17 August 2007.

${ }^{6} \mathrm{R}$. Weitz, 'Shanghai summit fails to yield NATO-style defence agreement', Jane's Intelligence Review, August 2006, pp. 41-42. 
Firstly, the features of military and political activities were combined. For the first time a political summit (Bishkek 2007) was amalgamated with war games ('Peace Mission 2007'). Moreover, until then defence ministers were the highestranking officials to watch SCO military exercises. The Heads of States' presence at the war games, for the first time in the history of the SCO, was probably to demonstrate the growing significance of the military component within the SCO but also signalled their determination to be in command of the security situation in this region. Secondly, there is the phenomenon of 'military assistance' as a concept. Perhaps the most significant development with regard to the security policy aspects of 'Peace Mission 2007' was the scenario in which military assistance played a central role. One of the vital ingredients of a mature security organisation, which also applies to the CSTO, is military assistance. Although a development towards inclusion of such an article into the policy documents of the SCO cannot (yet) be discerned, the scenario of 'Peace Mission 2007' unmistakably revealed a de-facto application of military assistance. Thirdly, since 2002, the military exercises of the SCO, have become increasingly ambitious, developing from a bilateral or multilateral level to a joint all-SCO level, and including not only counter-terrorism but also external security policy connotations. Furthermore, prior to the 2007 Bishkek Summit, on 27 June 2007 the SCO ministers of Defence reached agreement on a structural arrangement for joint exercises. According to the Kyrgyz Defence minister, Ismail Isakov, this agreement would lay the long-term organisational and legal foundations for such activities in the future. ${ }^{7}$ Fourthly, the 2006 Shanghai Summit affirmed that, in case of threats to regional peace, stability and security, SCO members would have immediate consultations on effective response to the emergency. Furthermore, the intention was expressed of formulating a mechanism for measures in response to threats to regional peace, as well as a study on establishing a regional conflict prevention mechanism within the SCO framework. The projected drafting of such security mechanisms, which are also found in NATO, were repeated at the 2007 Bishkek Summit. ${ }^{8}$

A final development indicating that the SCO might be developing towards a mature and comprehensive security organisation, is the intensifying relationship

7 'SCO Defence Ministers gather in Bishkek', 27 June 2007, http://www.sectsco.org/html/01465.html; 'SCO member states to increase defense co-op', Xinhua, 27 June 2007; Karniol, 'China, Russia expand "Peace Mission 2007"', 25 July 2007.

${ }^{8}$ Declaration on Fifth Anniversary of Shanghai Cooperation Organisation, SCO website, 15 June 2006, http://www.sectsco.org/html/01470.html; 'Joint Communique of meeting of Council of Heads of SCO Member States', SCO website, 16 August 2007, http://www.sectsco.org/html/01651.html. 
between the SCO and the Russian-led military alliance, the Collective Security Treaty Organisation (CSTO) of the Commonwealth of Independent States (CIS). Since this might become a crucial aspect of the SCO's move towards a more comprehensive security organisation, the relationship between CSTO and SCO will be dealt with in more detail below.

\section{Intensified ties between the SCO and the CSTO}

The origin of the CSTO is that in May 1992, within the framework of the CIS, a treaty for collective security (CIS Collective Security Treaty, CST) was signed in Tashkent with a currency of five years and the possibility of prolongation. The treaty comprises the desire of parties to renounce the use or threat of force. Furthermore, in its Article 1, the treaty forbids parties to join other military alliances. Just like NATO, the CST has a military assistance provision (Article 4), which states that aggression against one party will be considered as an attack on all parties. ${ }^{9}$ In 1999 , the presidents of Russia, Belarus, Armenia, Kazakhstan, Kyrgyzstan and Tajikistan signed a protocol to prolong the CST for five years. Azerbaijan, Georgia and Uzbekistan - who in the mean time had followed a policy away from Russia towards the West - refused to sign the protocol and subsequently withdrew from the treaty.

In 2002, the six remaining CST parties signed a charter, which transformed the CST into an organisation, the Collective Security Treaty Organization (CSTO). In 2005, until then US ally Uzbekistan demanded US forces to leave the base on its territory, as a result of US and European criticism of the beating down of the unrest in Andijan by Uzbek authorities earlier that year. Subsequently, Uzbekistan looked for closer ties with Russia. On 23 June 2006, Vladimir Putin announced that Uzbekistan would (again) join the CSTO as a member. Russian analysts think Uzbekistan's President Karimov's main argument for joining the CSTO is his need for Russian protection against a regime change like the ones that took place in Georgia, Ukraine, and Kyrgyzstan. ${ }^{10}$ According to the Russian President Putin, the main responsibilities of the CSTO are cooperation in defence, the manufacturing of weapons, training of military personnel, and peacekeeping activities. Other areas of

9 'Dogovor o kollektivnoy bezopasnosti', Tashkent, 15 May 1992, CSTO website, http://www.dkb.gov.ru/start/index.htm.

${ }^{10}$ V. Socor, 'Uzbekistan accedes to collective security treaty organization', Eurasia Daily Monitor, 27 June 2006; 'Sozdayetsa Evrazyjskaya Semerka', Nezavisimoye Voyennoye Obozreniye, 28 October 2005. 
cooperation are a common integrated air defence system and the fight against terrorism and narcotics, which particularly concerns the CSTO in Central Asia. ${ }^{11}$

\section{Military components of the CSTO}

The CSTO has at its disposal a joint headquarters in Moscow and a collective rapid reaction force. This collective reaction force consists of 4 000-4 500 soldiers, and is composed of three battalions from Russia and Tajikistan, two battalions from Kazakhstan and Kyrgyzstan, units of Russia's military base in Tajikistan, as well as the military aviation group of Russia's airbase in Kant, Kyrgyzstan. ${ }^{12}$ On 6 October 2007, at a CSTO Summit in the Tajik capital Dushanbe, the organisation announced decisions to increase military cooperation. At the request of Russia, the member states agreed to buy military arms and equipment from Russia at domestic Russian prices.

Furthermore, it was decided at the 2007 CSTO summit that its collective rapid reaction force in Central Asia would be supplied with modern materiel before the end of 2010. Another Russian initiative adopted at the 2007 summit was the foundation of a joint military force for peacekeeping operations. The concept of a joint peacekeeping force encompasses the formation of brigades capable of conducting peacekeeping missions, if necessary also outside the territory of the CSTO. According to the Russian Minister of Foreign Affairs, Sergei Lavrov, contingents will not be deployed in the so-called 'frozen conflicts' in the South Caucasus i.e., the separatist regions in Georgia and the Nagorno Karabakh area. ${ }^{13}$

\section{Central Asia as point of focus for the CSTO}

The CSTO has divided its area into three military regions: a European, a Caucasian and a Central Asian grouping. Recent CSTO documents and statements by officials put the emphasis on Central Asia and to a lesser extent on Europe or on

\footnotetext{
${ }^{11}$ M. Kaczmarski, 'Russia creates a New System to Replace the C.I.S.', Power and Interest News Report, 21 December 2005; 'Moscow reinforces military cooperation with CIS allies', RFE/RL, Vol. 9, No. 120, Part I, 24 June 2005. 'Korotko: Mirotvortsy ot ODKB', Nezavisimoye Voyennoye Obozreniye, 26 May 2006.

12 Collective Security Treaty Organization, http://www.eurasianhome.org/xml/t/ databases.xml?lang=en\&nic=databases\&intorg=5\&pid=24. R. Weitz, 'Shanghai summit fails to yield NATO-style defence agreement', pp.41-42; E. Marat, 'Fissures in the force', Jane's Intelligence Review, June 2007, p. 26.

13 'Gendarme of Eurasia', Kommersant, 8 October 2007, http://www.kommersant.com/p812422/CIS_CSTO_Russia_Lebedev/.
} 


\section{1}

the Caucasus. ${ }^{14}$. The return of Uzbekistan to the CSTO in 2006 - after the related forced withdrawal of US forces from that country - is one of the indications of the increased focus of the CSTO on Central Asia. Evidence to this fact is also the desire of the CSTO to deploy a considerable military contingent in that region, consisting of units of the Central Asian member states. The organisation has already stationed its collective rapid reaction force in the area but, according to CSTO Secretary General Nikolai Bordyuzha, it will further enhance its military build-up in the Central Asian region. The endeavours of the CSTO in Central Asia have an influence on its relationship with other security organisations active in this region. In terms of NATO, for instance, the CSTO has expressed its intentions to develop relations with this Western alliance, but has also criticised NATO and the US for causing instability in Central Asia. ${ }^{15}$ Likewise, NATO could well view the enlargement of the CSTO military contingent in Central Asia as a step to counterbalance its eastward expansion and to keep CIS countries under Russia's military protection. In relation to the SCO, the CSTO has proposed to work together on the reconstruction of Afghanistan. According to Bordyuzha, the CSTO together with China and the SCO should prevent the Taliban to regain power in Afghanistan. ${ }^{16}$

\section{An intensifying relationship between $C S T O$ and $S C O$}

The development of closer ties between SCO and CSTO has not been an easy process. First, Uzbekistan prevented a strengthened connection and later on China took that role. Already in 2003 Russia had the intention to bring the two organisations closer together, for the purpose of increasing the fight against terrorism and against drug trading, but probably also to form an 'Eastern bloc' against Western military involvement in the Central Asian region, in and around Afghanistan. In the process of enhancing the link between the CSTO and the SCO, Uzbekistan threatened to leave the SCO as a result of its aversion of the CSTO. A second reason for the resistance of Uzbekistan against closer ties was its power struggle with Kazakhstan on hegemony over Central Asia. Thirdly, Uzbekistan spoke out against military exercises of the SCO on its territory, which it rather

14 J. H. Saat, The Collective Security Treaty Organization, Central Asia Series 05/09, Swindon: Conflict Studies Research Centre, UK Defence Academy, February 2005, pp. 8 and 10; I. Plugatarev, 'Varshavskyj dogovor vozrozhdayetsa', Nezavisimoye Voyennoye Obozreniye, No. 24(433), 1 July 2005, p. 2.

${ }^{15}$ 'Russian defense minister says CSTO could expand', RFE/RL, Vol. 9, No. 223, Part I, 1 December 2005.

16 'CSTO proposes to SCO joint effort on post-conflict Afghanistan', RIA Novosti, 31 July 2007; 'CSTO plans to expand its military contingent', RIA Novosti, 14 May 2007, http://en.rian.ru/world/20070514/65444995.html. 
conducted in cooperation with NATO. Resulting from this stance, in 2003 Uzbekistan did not participate in joint SCO drills in Kazakhstan and China, because of a possible involvement of the CSTO in these manoeuvres. ${ }^{17}$

In 2006 - the year that Uzbekistan returned as a member state of the CSTO chances for a deepening of the relations between the SCO and the CSTO seemed to improve. In May of that year, SCO Secretary General at the time, Zhang Deguang, stated that the Council of Ministers of Foreign Affairs of the SCO had instructed the SCO Secretariat to arrange cooperation with the CSTO in the field of security. However, a year later, in April 2007, expectations had proved to be too optimistic. The negotiations on a Memorandum of Understanding (MoU) between both organisations - of which the text was completed and only awaited signing - had come to a deadlock, as a result of Chinese reluctance.

According to China, the CSTO, with its collective military force and a military assistance article, is primarily a political-military organisation, but the SCO should remain to be a political-economical organisation. China fears that a closer relationship between the CSTO and the SCO might give the impression to the outside world that the SCO endeavours to become a 'NATO of the East'. Since China would like to keep all (trade) doors open, it regards such a development as counterproductive to its economic and political interests. In addition to delaying the MoU, China also prevented the CSTO from contributing to the 'Peace Mission 2007' military exercises of the SCO. In November 2006, China had rejected the proposal of the Russian Chief of the General Staff, Yuri Baluyevsky, to make the 2007 drills a SCO-CSTO event. ${ }^{18}$ Apart from China's fear for a transformation of the SCO into a military alliance, another reason for its objections to further CSTOSCO cooperation is probably that this might strengthen Russia's position in the SCO by bringing in two of its satellites, Armenia and Belarus.

In spite of the Chinese reluctance, the CSTO continued its efforts to strengthen the cooperation between the two organisations. For instance, in July 2007 the CSTO called for joint action with the SCO with regard to Afghanistan. Not withstanding

17 S. Luzhanin, 'Na puti k "Aziatskomu NATO", Nezavisimoye Voyennoye Obozreniye, 26 May 2003, p. 10; V. Mukhin, 'ShOS i ODKB obyedinyayutsya', Nezavisimoye Voyennoye Obozreniye, 25 June 2003, p. 5.

${ }^{18}$ Interview by SCO Secretary General Zhang Deguang to ITAR-TASS News Agency, Beijing, 23 May, 2006, SCO website, http://www.sectsco.org/ news_detail.asp?id=893\&LanguageID $=2 ; \mathrm{V}$. Litovkin, 'Poka ne srastayutsha ...', Nezavisimoye Voyennoye Obozreniye, 13 April 2007, p. 2. 
the Chinese posture, probably at the request of Russia, the Bishkek 2007 Summit of the SCO in its final declaration optimistically mentioned the growing cooperation between the SCO and the CSTO. The declaration by the Heads of State specifically stated support for a further deepening of the relations between the two organisations, with the aim of coordinating efforts on strengthening regional and international security and counteracting new challenges and threats. ${ }^{19}$ On 5 October 2007, during a CIS summit in Dushanbe, the signing of the MoU between SCO and CSTO finally took place. Presumably, to receive consent from China, the agreement comprised a MoU between the Secretariats of both organisations and not between the organisations themselves, although in practise that will not make any difference. The fields of cooperation, as mentioned in the MoU, are:

- $\quad$ ensuring regional and international security and stability;

- $\quad$ counteraction against terrorism;

- the fight against drug trafficking;

- the fight against arms trafficking;

- counteraction against transnational organised crime; and

- $\quad$ other areas of mutual concern.

At the singing of the MoU, CSTO Secretary General Bordyzha explicitly stated that this cooperation between the two Eastern organisations was not directed against NATO. On 4 December 2007, SCO and CSTO held their first meeting on the areas of cooperation, as declared in the MoU, in Moscow. ${ }^{20}$

19 'CSTO proposes to SCO joint effort on post-conflict Afghanistan', RIA Novosti, 31 July 2007; 'SCO and CSTO set to sign MoU', 1 August 2007, SCO website, http://www.sectsco.org/html/01592.html; 'Joint Communique of meeting of Council of Heads of SCO Member States', SCO website, 16 August 2007, http://www.sectsco.org/html/01651.html; I. Safranchuk, 'ShOS na marshe. ODKB v oboze?', Nezavisimoye Voyennoye Obozreniye, 24 August 2007, p. 3.

${ }^{20}$ Memorandum of Understanding between SCO Secretariat and CSTO Secretariat, SCO website, 5 October 2007, http://www.sectsco.org/html/01786.html; 'Security alliances led by Russia, China link-up', Daily Times, 6 October 2007, http://www.dailytimes.com.pk/print.asp?page=2007\10\06\story_6-10-2007_pg4_3;

V. Litovkin, 'ODKB i SMI protiv terrorisma', Nezavisimoye Voyennoye Obozreniye, 2 November 2007, p. 1; 'Consultations held by SCO and CSTO Secretariats', SCO website, 4 December 2007, http://www.sectsco.org/html/01915.html; S. Blagov, 'Eurasian groupings seek closer security ties', ISN Security Watch, 13 December 2007. 
A sequence of events in 2007 has demonstrated considerable progress towards a closer relationship between the CSTO and the SCO, namely:

- $\quad$ the CSTO's proposal for joint action towards Afghanistan;

- the presence of CSTO observers - although not as participating organisation - at the 'Peace Mission 2007' exercises;

- the final declaration of the 2007 SCO Bishkek Summit; and finally

- the signing of the MoU between the SCO and the CSTO as the climax.

Since the CSTO is a purely military alliance, the cooperation will undoubtedly reinforce the military component of the SCO. Therefore, in the near future, joint SCO-CSTO action may possibly develop. If the SCO will endeavour to proceed on a way towards a full-grown security organisation, then closer ties with the CSTO will be helpful. Essential elements of a professional security organisation, such as rapid reaction forces and a military assistance article, are part of the framework of the CSTO. With the majority of the states sharing membership of both organisations, it will be easy for the SCO to adopt such instruments as well, if so desired.

\section{Energy security as the new dimension of security policy}

In addition to military-political issues, energy security, which increasingly is identified as a vital element of security policy, is gaining ground in the SCO. In July 2007, the SCO Energy Club was established, with which the SCO may aim for a common energy approach, above all in strengthening energy security. Thus, as with the military manoeuvres, bilateral or multilateral energy cooperation among SCO members is developing into a common SCO energy approach, although it is still unclear what this would entail.

\section{Common energy policy: the SCO Energy Club}

At the Shanghai Summit of 15 June 2006, energy was publicly put on the agenda as a major issue for the first time. At this summit, Russia's President Putin announced the intention of the founding within the SCO of an Energy Club, in order to develop a joint SCO course of action in the field of energy. At a meeting of the Heads of Government Council of the SCO in Dushanbe, Tajikistan, on 15 September 2006, a common energy policy was further discussed. At the outset, priority areas of cooperation concerning energy, transportation and telecommunications, were defined. The creation and launch of special working groups in the fuel and energy sector, as well as for modern information and 
telecommunications technology received special emphasis. Furthermore, decisions took place on implementing the initiative voiced by Vladimir Putin at the Shanghai Summit, where he proposed to set up a SCO Energy Club.

The Heads of Government tasked a special working group on fuel and energy with studying in the shortest time the possibility of forming a SCO Energy Club. The Kazakh and Russian parties would present to the SCO Secretariat their proposals for all parties to be discussed in 2007 at a meeting of the heads of fuel and energy departments of the SCO member states. On 3 July 2007, the SCO Energy Club was established in Moscow. The regulations of the Energy Club - in which the SCO observers also take part- explain that the Club unites energy producers, consumers and transit countries in coordination of energy strategies with the aim of increasing energy security. At the 2007 Bishkek Summit of 16 August 2007, Russian Foreign Affairs Minister Lavrov confirmed an active role for the SCO observers in the Energy Club, for instance participation by the energy companies of the observers. ${ }^{21}$ Although so far energy deals have been made bilaterally, the foundation of the SCO Energy Club is a step towards a common energy policy, even though the intentions of the Club remain unclear.

Western assessments sometimes view the SCO as increasingly becoming a mechanism to oust the USA and its Western allies from Central Asia, and thus to threaten Western security interests. The SCO Energy Club could likewise be regarded as a threat to Western (energy) security. Iran's proposal to set gas prices and to control its gas flows together with Russia, as a so-called 'gas OPEC' only reinforced this fear, even though Iran's proposal is to a large extent propaganda. However, SCO member countries that export oil and gas are not only partners, but also rivals on the promising markets in East and South Asia. China, for instance, is attempting to get a foothold in the energy sectors of Turkmenistan, Kazakhstan and Uzbekistan. The latter three countries are beginning to threaten Russia's position in Central Asia based on a monopoly on export gas pipelines to Europe. Thus, there is much diversity among SCO members and observers on energy cooperation among

21 'Joint Communiqué of 2006 SCO summit', http://english.scosummit2006.org/ en_zxbb/2006-06/15/content_756.htm; 'Energy outcome of SCO meeting in Dushanbe', 20 September 2006; 'Meeting of the Council of Heads of Government /Prime Ministers of SCO', Dushanbe, 15 September 2006, http://www.sectsco.org/html/00030.html; 'Poyavitsya Energoklub ShOS', 3 July 2007, http://www.scosummit2007.org/news/press/62/; 'Polozheniye ob energeticheskom klube', 3 July 2007, http://www.scosummit2007.org/ files/material/polozhenie_energ_kluba.doc; 'Moratorium on admission to Shanghai Six to hold - F. M. Lavrov', RIA Novosti, 16 August 2007. 


\section{6}

themselves as well with the West, instead of a simple unification on or against such issues. Whether a common SCO energy policy will change this diversity, remains to be seen.

\section{Military aspects of energy}

Security organisations tend to become involved in energy security, in the sense that they realise that security nowadays not only entails military, but also energy issues. This applies to NATO, but also to the CSTO. The security of oil and gas pipelines against terrorist attacks has already become a task of the CSTO. Since 2004, the CSTO has been responsible for the protection of railway lines, which, like energy, is related to strategic economic interests. As to the guarding of energy installations, the Anti-Terrorist Centre of the CIS has conducted an anti-terrorist exercise - with units of the CSTO participating - at a nuclear energy station in Armenia in September 2006. Earlier, in August 2005, this CIS Anti-Terrorist Centre had held an exercise around the Kazakh city of Aktau, while on the Caspian coast armed forces were to counteract terrorists that had seized an oil tanker. Furthermore, during the CSTO's joint military exercises in June 2006 in Belarus, one of its objectives was the protection of gas and oil pipelines, which further confirmed the CSTO's conceptual development towards energy security tasking. ${ }^{22}$ So far, the SCO does not have rapid reaction forces, and thus no specific joint military tasking. Nonetheless, in the light of the aforementioned steps of the SCO towards a mature security organisation, as well as the emergent cooperation with the CSTO and the recently started SCO Energy Club, this situation might well change. Since the SCO states also have to cope with terror attacks, possibly also against their energy infrastructure, it is not unlikely that the SCO will create standing reaction forces in the near future with security of energy infrastructure and of transport routes as one of its tasks.

\section{Relationship with the West}

The SCO is unlikely to turn into an anti-Western club. Russia wants to use the SCO for its anti-Western aims but others, for instance China and Kazakhstan, who maintain strong economic cooperation with the West, will probably not allow it.

22 I. Plugatarev, 'Karaul u truboprobodov mozhet prinyat ODKB', Nezavisimoye Voyennoye Obozreniye, 9 June 2006, p. 2; S. Blank, 'The great game goes to sea: naval rivalries in the Caspian', Central Asia - Caucasus Analyst, 11 January 2006; I. Plugatarev, 'ODKB budet zashchishat' truboprovody', Nezavisimaya Gazeta, 16 June 2006. 


\section{7}

Although the West at present does not have anything to fear from the SCO, the SCO's current endeavours in the security dimension might encourage the West at least to observe further activities of the SCO closely, if not possibly also to seek cooperation with this organisation. In spite of the anti-Western stance as declared at the Astana Summit of 2005, the SCO has the potential to become a partner of NATO. The SCO's Secretary General at the time, Zhang Deguang, stated that the $\mathrm{SCO}$ is open to cooperation with NATO on issues of mutual interest. ${ }^{23}$

\section{Partnership between SCO key players China and NATO}

NATO has arrangements for cooperation with all SCO states except China. Since the beginning of the $90 \mathrm{~s}$, this alliance has had bilateral cooperation with the five Central Asian states within its Partnership for Peace framework, as well as a special relationship with Russia, which since 2002 is called the NATO-Russia Council. China frequently states its suspicion towards NATO's actions in the South East Asian region. ${ }^{24}$ The concept of forming 'global partnerships' with countries such as Japan, South Korea, Australia and New Zealand, that already cooperate with NATO, for instance in Afghanistan - a matter still lacking consensus within NATO - especially annoys China. China disapproves of NATO's military action in the region, which it considers to be its sphere of influence. Furthermore, NATO and China both seem to be hesitant to enter into a dialogue with each other.

With the cautious development of the SCO towards becoming a mature security organisation and NATO operating in Afghanistan, and considering global tasking, it certainly seems time for action. In a way, the current situation in South East Asia is comparable with Eastern Europe in the 90s. At that time, the Warsaw Pact as well as the Soviet Union had collapsed and the newly independent states were seeking closer ties with NATO. Likewise, the regional power, Russia, was suspicious and critical of these developments. When it became clear that former Warsaw Pact states would be allowed to join NATO, the alliance realised that an appeasing effort towards Russia was necessary to maintain the dialogue with this power and to avoid disputes. Thus, a special partnership with Russia was established. Equally, with a comparable situation in South East Asia, NATO should take such a step towards China. A special partnership, similar to the NATO-Russia Council, could be created with China, within which views can be exchanged and military cooperation can be

${ }^{23}$ R. Weitz, 'Shanghai summit fails to yield NATO-style defence agreement', p. 43.

${ }^{24}$ F. P. van der Putten, 'De betekenis van China's opkomst voor de NAVO', Internationale Spectator, July/August 2007, p. 357. 


\section{8}

arranged. Such a move would build confidence and thus diminish any possible suspicion on both sides.

\section{Operational cooperation between NATO and SCO}

The same applies to NATO and the SCO developing a special partnership. Until now, NATO has been reluctant to cooperate with the CSTO. However, in the case of the SCO, the organisation is not only led by Russia but also by China, which prevents it from being an instrument of Russian (anti-Western) security policy. In November 2005, the SCO established a contact group with Afghanistan. At the Bishkek Summit, the SCO, member states stated their concern about the destabilising situation in Afghanistan, which affects Central Asia. Considering their geographical and military presence around Afghanistan and the threats with which both NATO and the SCO are confronted, namely drug trafficking and terrorism by Taliban and Al Qaida, joint activities are feasible. The CSTO has proposed joint action with the SCO in preventing the Taliban from returning to power in Afghanistan. China, who is usually disinclined to have closer ties with the CSTO, while being aware of the threats in the region, might consider cooperation between SCO and NATO a better way to deal with these problems. ${ }^{25}$

Since the SCO and NATO clearly share an interest in improving security and stability in Afghanistan, it would be wise to combine efforts and forces. Furthermore, it is doubtful whether the Central Asian states - although stressing their self-determination in regional security - would be able to counter threats such as those of the Taliban and Al Qaida by themselves. SCO states could join NATO with contingents in ISAF (International Security Assistance Force) in Afghanistan. Thus, SCO armies would be incorporated in an experienced military-operational infrastructure to fight mutual threats. Such an effort would be beneficial in two ways. Firstly, it would strengthen the capabilities of ISAF in the war against the Taliban. Thus, this would promote stability in Afghanistan and subsequently also elsewhere in Central Asia, as desired by the SCO states. Secondly, operational cooperation between the SCO and NATO would also improve the political relationship between both organisations. In addition to participating in a NATO-led operation, the SCO could also join NATO in exercises, which would also contribute to operational experience as well as political relations. In cooperating in such ways,

25 'CSTO proposes to SCO joint effort on post-conflict Afghanistan', RIA Novosti, 31 July 2007; SCO Bishkek Summit website, http://www.scosummit2007.org/ en/results_; 'Bishkekskaya Deklaratsiya', SCO website, 16 August 2007, http://www.scosummit2007.org/news/press/148/. 
the SCO and NATO can reduce distrust but also work together to improve stability in the Central Asian region. This will not mean that divergent views will then have disappeared, in particular when it comes to human rights and promotion of democracy, but these issues can also be openly discussed in a cooperation platform. Such an approach is better than maintaining the current wait-and-see policy of NATO and SCO.

NATO's Bucharest Summit of 2-4 April 2008 has brought a possible NATOSCO cooperation on Afghanistan a step closer. At the Summit, Russia agreed to grant transit rights to NATO, when transport of non-military goods from the West to ISAF in Afghanistan is involved. Furthermore, the Summit was also attended by the presidents of Turkmenistan and Uzbekistan. Transport from Europe via Russia to Afghanistan inevitably has to pass Central Asian states. At the conference, Uzbek President Karimov stated that he too was prepared to allow transit of NATO freight over the territory of his country. ${ }^{26}$ Later on, Turkmenistan also granted NATO such transit rights. This willingness of Russia, Turkmenistan and Uzbekistan might mean a break-through in not only bilateral ties between former Soviet republics and NATO but also in cooperation between NATO and the SCO, which would be beneficial for Afghanistan and Central Asia in general but also for improved relations between the two security organisations.

\section{Outlook on the future of the SCO}

The SCO has developed itself from (originally) a border arms control-oriented organisation, via a regional counterterrorism body, to a truly international entity. The developments in the military field and in energy security display the growing importance of the security dimension as part of the SCO framework in the international arena. In addition, these developments can be regarded as at least a partial maturing of the SCO as a security organisation. Until recently, the nature of the organisation was mainly political and economic. However, the developments as described indicate a closer cooperation in the field of security. With its capacities and experience in joint military forces and a military assistance concept, the CSTO can be a vital partner in supporting the SCO to transform into a comprehensive

26 'NATO-Russia Council meeting concludes the Bucharest Summit', NATO website, 4 April 2008, http://www.nato.int/docu/update/2008/04-april/e0404b.html; 'Uzbek president offers NATO a transit corridor to Afghanistan', AP, 3 April 2008, http://www.pr-inside.com/uzbek-president-offers-nato-a-transit-r519172.htm;

'Uzbekistan offers assistance to NATO in Afghanistan', RIA Novosti, 4 April 2008, http://en.rian.ru/analysis/20080407/103955181.html. 
security organisation. Nevertheless, the SCO still lacks a considerable number of essential elements, which NATO, as a mature security organisation, has, namely an integrated military-political structure with permanent operational headquarters, a rapid reaction force, and continuous political deliberations. Furthermore, an essential difference between the organisational development of the SCO and NATO is the fact that NATO is aimed primarily at external security risks whereas the SCO concentrates strongly on security within the territory covered by its member states. Especially China seems committed for the time being to maintain this situation. Moreover, SCO member states and observers cooperate in many areas but also illustrate large differences, such as contradictory political and economic interests. These internal differences might prevent further progress of the SCO, also in the development of its security component. However, in spite of these shortcomings and inward-looking focus, the intensification of the SCO security policy is such that a cautious development towards a more full-grown security organisation - with a scope of activities and an intensity of cooperation similar to that of NATO - can no longer be excluded. If this is the desire of the SCO member states, such development will still take a considerable number of years before the SCO can truly be described as the 'NATO of the East'. 